\title{
When Scripts of Nationalisms are not Celebrated: Scenario of Recent Violence in India
}

\author{
Thomas M John* \\ formerly working as Assistant Professor at Allahabad Bible Seminary and served as Assistant Program Director of Centre for Dalit and \\ Minority Studies New Delhi, India \\ *Corresponding author: Thomas M John, Assistant Professor at Allahabad Bible Seminary and served as Assistant Program Director \\ of Centre for Dalit and Minority Studies New Delhi, India, prasent live's in USA
}

\section{Review}

The recent violence between two communities which recently engulfed the capital city of India claimed nearly 50 lives being lost and several hundred being critically injured. In addition people suffered due to material losses and mental health traumas. We generally consider mob violence naturally erupts phenomena, therefore, no capital punishment for the rapist during violence in India. However, it is a serious symptom that when violence becomes part of a political and ideological script, then its implementation is a political must. We recently witnessed this political-ideological sanction that has been coupled with administrative judiciary impunity. This situation poses a question, why does our society fail to look beyond religious and ideological differences even though we claim to live in a democracy and we have a constitution that uphold rights and value? Why we failed to develop a mass-psyche that upholds humanity beyond differences? This question seeks to investigate an in-depth analysis of culture, economy and political nexus that stitch together the fabric of a nation.

Analysing economic, cultural and political condition is one of the toughest jobs to be undertaken, since convolutions, uncertainties, opportunisms rule over ideologies, philosophies and values. Analytical prediction therefore is not as easy to make as earlier but still symptoms of the society can be read and certain assumptions made. However, to a certain extent cyclic nature of history helps us to read and reflect on the present.

This article discusses a vast topic within a simple logical framework, which has its own limitations. The framework for the discussion of this paper is as follow: Firstly, Indian politics function within a framework of ideologies as well as philosophies; on one side, those are used as a medium to gather public opinion and on other side to gather the interest of the few. Those are used in the most convincing way possible to influence people by the effective manipulation of people's feelings, emotions, identities and reason. The major question, addressed by the ideologies and philosophies, is 'what does integrate people together as a nation? If we call that integrating factor/s as nationalism, then, what do we mean by nationalism ? $^{1^{\prime}}$ Though this is a very old political question, still world turns around on this fulcrum. Political debate in the USA, unrest in Middle East, South Asia, Korea, Japan and others address this question every day in their politics, economy, culture and religion.

To understand the relevance of this question in Indian scenario, we need to identify the ideological and philosophical contexts and contentions between political parties. It is important to understand that in the Indian context there is not just one 'nationalism' but several. The major political frameworks that address this question, and define the meaning of nationalism are as follows:

I. Secular nationalism

II. Religious/cultural nationalism

III. Federal nationalism

IV. Subaltern Nationalism

Besides, there are various regional, linguistic, caste-based opposing ideologies in existence. They oppose one another ideologically and propagate their political philosophies by adding colour and glamour to it.

Secondly, Major political philosophies promote various cultural views; culture of the nation is defined in several specific ways.

${ }^{1}$ Since nationalism is a vast topic, it is not defined rather discussed throughout the paper. 
I. Secular culture

II. Cultural nationalism/Hindu Culture

III. Counter-cultures

IV. Cultural Federalism

As per the philosophy each one defines, 'who is Indian' and 'who is not'. Even we feel at times our constitution is side-lined. Thirdly, each view professes economic ideology. Though apparently all look same, with an exception of subaltern economies, they have differences. Discussion based on the framework set out above will give us a general picture of present day socio-politics, economic and cultural condition of Indian society.

\section{Ideological Struggle or Confusion to Perceive a Nation}

We live in the midst of ideological diversities and people belonging to different generations witness these diversities in different ways. A nation with good number of vibrant youths, many rich experienced politicians who mostly belong to older generations, and ordinary people, educated and uneducated, with gender diversities, various races, languages, religions, regions, and castes etc. will always have a problem here. Because they will always address this question in different ways. They have difficulty in perceiving this question in a unified manner.

Nevertheless, along with differences, we have bonds of unity, which are located through underlying principles, ethos, and values, which work together as a mechanism of integration. Our mechanism of integration historically as well as politically was developed and became an essential feature of the nation. It is more or less a conception rather than a definition. However, one of the best explanations of national integration can be found in the interim report of the sub-group on National Integration Council of India, which writes:

"The concept underlying national integration, shorn of all verbiage is to attain a particular kind of consciousness in every citizen of the Republic of India which will enable him or her to feel that he or she, transcending the primordial divided of our ancient society thinks and acts as citizens of India first. This in turn means territorial identification with the whole of India. It also means primary loyalty to Indian nationhood and a refusal to agree to that primary loyalty being corroded or eroded by considerations of caste, religion, region and language.

In brief it (national integration) means that the citizens of India should be the promoter of the idea of nationalism based on civic consciousness rather than narrower consciousness implicit in our history and geography²."
Nationalism is the major element that plays dominant role in defining a nation and what it identifies as. Discussion of this term is well rooted in Indian history as well as World history.

In India, it is generally perceived that nationalist feelings (consciousness) were developed as the backdrop of colonialism; development of this concept for a political freedom grew against colonial power. Our freedom fighters could inject the masses with a feeling called 'nationalism,' they grasped it in a political sense. At the same time, some elites and upper caste members interpreted it as meaning the maintenance of social structural domination. They did this by presenting it as a culture of a nation called Bharat and they found their roots in the epics. Both concepts on Nationalism were rejected by Ambedkar and Communists thinkers. The former raised his objection to the general perception on nationalism on the basis of the view of millions of untouchables, who couldn't dream of a nation, since the concept of nation can't be simply comprehended as feeling; rather it is relational; related to territory and other factors, therefore for them (untouchables) nationalism was just a dream without a nation. But for the Communists, the concept of 'nationalism' that they saw promoted was a nationalism of bourgeoisie.

Today, a group who expressed their dissent soon after independence came to the forefront through democratic process. They again triggered the question of nationalism and national integrity and are forming a consciousness of a form of nationalism which demands that in principle, Indian Muslims and Christians must leave. They accelerated their effort of interpreting every culture and practices of all caste groups and former untouchables as Hindu culture. Such integration would define Bharat (India). They interpret folk-theologies as essentially a reflection of Brahminical theology or co-opt them forcefully through myths, which M. N. Srinivas calls as 'Sanskiritization'. Today's political scenario gives full confidence to early sanskritization movement and enters into the realm of education, the judiciary and so on. Fundamental faction thus foresees a new saffronized nation.

Academic arena is once again active with a question-what integrates a nation? Various answers to this question divide Indian politics, economy, educational system, theological perceptions, and cultural identities. A healthy ideological contest and contentions of the term 'nationalism' is necessary to lead this nation further. If healthy contest and contentions are curbed, that is the end of real progression and development because India has ever-deepening multi-layered diversity. Keeping this in mind, this paper invites its readers to have a bird's eye view on present day Indian politics, culture and economy, as seen through the spectrum of various forms of Nationalism.

${ }^{2}$ See Agenda for the meeting of Standing Committee of National Integration Council, 23 June 1987 (New Delhi, Ministry of Home Affairs) 4. 


\section{Secular Nationalism, Composite culture (Secular Culture) and (Secular) Neo-liberal Economy}

Secular nationalism was articulated by Nehruvians and occasionally by Nehru himself. There are various perceptions of nationalism and Nehru consciously defined the very nature of India by defining what kind of nationalism India looked forward to. Backdrops of Nehruvian concept of nationalism will well define what secular nationalism is meant for and looking at the practical side of secular nationalism will help us to appraise this ideology.

Historically nationalism as a concept can be divided in number of ways. S. Gurumurthy divided Nationalism into three ways ${ }^{3}$ : firstly, as a modern term it has its roots in Europe; secondly, in a pre-modern sense nationalism was perceived as a consciousness: in the case of Jewish nationalism, the Jews were without a nation and Roman Eagle floated everywhere but Roman nation is limited, and thirdly, in ancient times the Indian nation was Bharat as one nation but multiplicity of states.

India as a nation is not merely rooted in an ancient sense of nationalism since that ancient sense was the creation of a small section of society and even calling a nation by the epic term 'Bharat' is an injustice to major section of Indians.

The spirit of nationhood of India abides in the constitutional bodies, which function in accordance with the requirements of the Constitution, which has its roots in modern sense of nationalism. In brief we can say India as a nation is not standing merely on muchglorified past based on domination and subordination but on the values which were shaped by contest and contentions.

From a mere foolishness of mythical imaginations, Indian think-tanks could move forward by letting themselves out from Punyabhumi. They were enlightened and acquired a sense of evaluation through their interaction with the history of the world, including the history of Europe. History of Europe was shaped through one of the most powerful political philosophies called Nationalism. With the collapse of the imperial state system in Europe, certain ethno-religious and ethno-linguistic entities, usually called nations, claimed territories for themselves in which each nation established their own collective political authority. ${ }^{4}$ Such interaction with the outside world enlightened the minds of a few, and they worked together to induce a spirit of nationalism in a political sense as the backdrop to colonialism and dreamed of a nation.

However, the perception of this term differs. In European context, this term was perceived theoretically in different ways: for Mazzini nationality is individuality of people, for Fichte emphasis on language and culture, for Spengler it is spiritual unity, for Hans Kohn it is a state of mind. According to Kohn Nationalism emerged out of two sources in Europe: one from the romantic background and another from liberal background. The first asserted feeling and identity and the second acknowledged civic rights of the people. Identity nationalism ${ }^{5}$ was from the Eastern Europe and Civic nationalism ${ }^{6}$ came from the Western Europe. (Kohn, 1965) However, the ideology of Nationalism, when it grew up in Europe, ${ }^{7}$ favoured the idea of political equality among the nationals. Thus the nation (ethnic) state transformed into democratic state, where state derived her sovereignty from its citizens and a space, i.e. civil society (plural entity), was being created to have an interaction of state with its citizens.

Majority of the third world countries adopted the idea of nationalism from the west but with their own emphasis, which ended up in projecting either a dominant language as national language, dominant religion as national religion or the culture of dominant group as national culture.

Indian Nationalism was understood/interpreted in different ways: Firstly, against the backdrop of colonialism, Nationalism was used predominantly as a political slogan for the political integration against colonial nations in Asia, Africa and South America.

Secondly, colonial policies produced religious nationalisms, the dominant form of which was termed as cultural nationalism. However, cultural nationalists claim their origin from the epics. Those who adopted the concept of civic nationalism implanted its values (liberty, equality and fraternity) within the foundation (constitution) of our nation and called India as secular, democratic and socialist nation, with equality, liberty, and justice

\footnotetext{
${ }^{3}$ Foreword by S. Gurumurthyin Purnima Singh, Indian Cultural Nationalism, (New Delhi, India First Foundation, 2004 ), 3.

${ }^{4}$ According to Hans Kohn, Nationalism is modern phenomenon with its origin clearly manifested in English Revolution of 17 th century and acquiring more mature character during the American and French revolution. At the same time he does not deny about the roots of various forms of nationalism in ancient Indian and Greek. Purnima Singh, Indian Cultural Nationalism, 33.

${ }^{5}$ D. L Sheth, “Minoritiy Identities and Nation States", Ed. By D. L Sheth and Gurpreet Mahajan, The Nation State and Minority Rights, (New Delhi: Oxford University Press, 1999), 20.

${ }^{6}$ Ethnic nationalism refers to nationalism as determined by descent. Attachment are inherited and not chosen, representing the exclusivist element of nationalism. Ethnic nationalism was active on behalf of the high culture. Since there were not the required foundations and institutions in place in society, they had to create one from what they had. This was likely to be language, culture, skin color, religion etc., this paved the way for exclusivism in ethnic nationalism.

${ }^{7}$ Civic Nationalism is exercised in those areas where there exists civil society. The sovereignty of the people is located in the individual (the citizen) whose national identity is a sense of political community within a demarcated area. National dignity is derived from the individual/citizen who in turn defines the national community. Civic nationalism is complementary to liberal democracy. In civic nationalism society is united by the concept of territoriality, citizenship, civic rights and law. All citizens are equal before the law.
} 
as the fundamental principles. These people were called secular nationalists over against cultural/religious nationalists. The term 'secular nationalism' has a unique meaning; Mark Juergensmeyer explains Hans Kohn used the term (secular) nationalism, as apolitical organization: “...in such an organization individuals are linked to a centralized, all embracing democratic political system that is unaffected by any other affiliations...the linkage is sealed by an emotional sense of identification with geographical area and a loyalty to a particular people, an identity that is part of feeling of nationalism ${ }^{8} . "$

However, Nehruvian followers practiced it in different ways. Though as a conceptitapparently looks good, in reality throughout these years, it is meant for a nation centred on Brahminic ${ }^{9}$ -leadership, together with various sub-leaders emerging from lower section of the society.

This view accepted the premise that a nation is defined by a common culture, but not ethno-religious culture, along with other requirements. This can be well termed as Cultural pluralism or Multiculturalism. This pluralistic culture, which is common, was defined by shared historical experience and joint struggle to build this nation. It was also constituted by cultural elements generated out of inter-penetration of beliefs, values and practices.

The congress rules almost sixty years, with the ideology of secular nationalism and cultural pluralism/composite culture. After around sixty years, there are many studies conducted to know the actual state of the people. One of those studiesis as follow;

Arundhadi Roy details in her book, Annihilation of Caste: the Saint and the Doctor, after forty years, in 1990, "the writer Khushwant Singh, in his piece called "Brahmin Power," stated that:

Brahmins form no more than 3.5 per cent of the population of our country ... today they hold as much as 70 per cent of government jobs (gazetted posts). In the senior echelons of the civil service from the rank of deputy secretaries upward, out of 500 there are 310
Brahmins, i.e. 63 per cent; of the 26 state chief secretaries, 19 are Brahmins; of' the 27 Governors and Lt Governors, 13 are Brahmins; of the 16 Supreme Court Judges, 9 are Brahmins; of the 330judges of High Courts, 166 are Brahmins; of 140 ambassadors, 58 are Brahmins; of the total 3,300 IAS officers, 2,376 are Brahmins. They do equally well in electoral posts; of the 508 Lok Sabha members, 190 were Brahmins; of 244 in the Rajya Sabha, 89 are Brahmins ${ }^{10}$.

After sixty years of effort to build a nation with secular ideology and composite culture, in reality what happened to some section is a puzzling question?

According to the CSDS study,

"47 per cent of all Supreme Court Chief Justices between 1950 and 2000 were Brahmins. During the same period, 40 per cent of the Associate Justices in the High Courts and lower courts were Brahmin. The Backward Classes Commission, in a 2007 report, said that 37.17 per cent of the Indian bureaucracy was made up of Brahmins ${ }^{11}$.

Brahmins have also traditionally dominated the media. Here too, what Ambedkar said in 1945 still has resonance: The Untouchables have no Press ${ }^{12}$."

Even today untouchables do not own any media ${ }^{13}$ therefore atrocities against untouchables are rarely reported.

Therefore, as a principle this concept is good, but in practice, congress gives a hidden meaning to it i.e. the Brahminic core of caste culture and traditions forms the centre around which diversities or caste, ethnicities and religions are accommodated.

Economic philosophy also has a composite nature; it begins from socialism, then liberal and moved towards Neo-liberal, moved in between security state and welfare state. One side they globalized Indian economy and on the other side addressed its consequences through welfare measures. More beneficiaries of globalized economy is higher caste since they could easily climb the competitive ladder, however economy failed to address the real

${ }^{8}$ It was grew up through a long period, spanning three centuries of intermittent wars, followed by peace treaties-beginning with Peace of Westphalia (1648), through the congress of Vienna (1815), treaty of Versailles (1919), and the settlement ending world war II. quoted

${ }^{9}$ Mark Juergensmeyer, Religious Nationalism (New Delhi: Oxford publications, 1998), 14.

${ }^{10}$ Brahmins are Higher caste in Indian caste system

${ }^{11}$ Arundhati Roy, Annihilation of Caste: B R Ambedkar, (New Delhi: Routledge, 014), 30.

${ }^{12}$ Ibid., 31.

13“ Out of the four most important English national dailies, three are owned by Vaishyas and one by a Brahmin family concern. The Times Group (Bennett, Coleman Company Ltd), the largest mass media company in India, whose holdings include The Times of India and the 24-hour news channel Times Now, is owned by the Jain family (Banias). The Hindustan Times is owned by the Bhartiyas, who are Marwari Banias; The Indian Express by the Goenkas, also Marwari Banias; The Hindu is owned by a Brahmin family concern; the Dainik Jag ran Hindi daily, which is the largest selling newspaper in India with a circulation of fifty- five million, is owned by the Gupta family, Banias from Kanpur. Dainik Bhaskar, among the most influential Hindi dailies with a circulation of 17.5 million, is owned by Agarwals, Baniasagairt. Reliance Industries Ltd (owned by Mukesh Ambam, a Gujarati Bania) has controlling shares in twenty-seven major national and regional TV channels. The Zee TV network, one of the largest national TV news and entertainment networks, is owned by Subhash Chandra, also a Bania. (In southern India, caste manifests itself somewhat differently. For example, the Eenadu Group- w'hich owns newspapers, the largest film city in the w'orld and a dozen TV channels, among other things- is headed by Ramoji Rao of the Kamma peasant caste of Andhra Pradesh, which bucks the trend of Brahmin-Bania ownership of Big Media. Another major media house, the Sun TV group, is owned by the Marans, who are designated as a 'backward' caste, but are politically powerful today.)” Ibid., 33. 
struggle of the lower sections and they are all always at the mercy of welfare of the state, which functions through caste structure.

\section{Religious Nationalism, (Hindu) Culture, Cultural- Neo-liberal Economy}

The dominant Cultural/Religious nationalists found their roots in the epics. However, as an ideology it developed during British period. They argued that our culture is rooted in a religion called Hinduism-Brahminical Religion, and so India's nationhood must be defined in terms of a common culture, a culture configured by a particular notion of Hinduism. Religion is the major determinant of nationalism. Christophe Jaffrelot recognizes that Hindu Nationalism emerged at the forefront as a distinct political ideology around the turn of the century in the north and north-west part of India and it was theorized in the 1920s. He further argues ideological construction of Hindu nationalism is a cultural strategy to defend Brahminical hegemony ${ }^{14}$.

The entire territory of the subcontinent was the home of Hindus; this meant other communities whose religion had its origins outside the subcontinent could live in India only at thesufferance of Hindus. Political faction of this concept is BJP-RSS. Now they rule a nation, which lived about sixty years with different ideological stream; bringing all the nation into their ideological way of thought is the biggest struggle they have ever had. They use many means such as gauoraksha, love-jihad,etc.to control people.

This view professes Hinduism as a cultural stream which flows through the nooks and crannies ofBharat, which has its colour and otheridentities. Being part of those identities and colour is the major requirement for a true national. They repeatedly emphasize dichotomy between 'national' and 'anti-national'. Devoted allegiance is called as 'national'; if anybody question he/she is called as 'antinational'. Here culture means nationalism and nationalism means culture. They promote religious and language-centred culture.

Economic policy of this faction, presently, can be termed as cultural neo-liberal economy. This term ispreferred here because Modi government represents a strikingly distinctive form of the Indian state shaped by neoliberalism which strategically evokes populist, traditional modes of cultural norms as a means of deepening market process.

Modi used 'economical issues' as a means to grab power in 2014, they highlighted 'black money' and succeeded in promoting those issues to the people with the help of major Media. Though, previous governments began to address this issue, it was too late and failed to get momentum due to series of scams along with media propagation. BJP knows tax-evasion happens everywhere in the world and the corporates as well as mighty middle men, who play big role in setting all the major arms and other deals, are the major culprits. They are untouched; to ensure that at the same time the common man should not get disappointed with the government's performance so Modi used another strategy 'ban all the high currencies' of the nation. Apparently, he tells it is to curb black money. In reality, he played another strategy to promote neo-liberal market economy and destroy all the local economies or allow the corporate world to handle all the transaction process of local economies. In a long run, they swallow local economies as well.

Here, we must read through programmes and regular rhetoric of the PM. The new imagination behind all the economy related policies are a shift from morality to statism, from systemic to individual, from exploitation to corruption, and from questioning to complete loyalty. Here government tries to moralise the politics and economy by infusing emotions into policy debates and reducing all debates into single question: Are you in support of government or not? Or are you a national? It is a very systematic effort of killing informal sector of economy under the cover of '(cultural) nationalism'. Economy functions through a strong security state and weak welfare state, strong corporate-centred stateand less people-centred one, benefits to corporates and merely cultural rhetoric and slogan to common man and development through cultural medium; marketing through culture.

\section{Federal Nationalism, Cultural Federalism, Federal- Neo-Liberal Economy}

Since India is a federal national state nationalism can be best termed as federal nationalism, which also can be termed by RajeevBhargava as coalescent nationalism. According to him, each cultural unit has potential to organize territorially. All these units see themselves as part of a larger, equally significant common culture, which forms the basis of coalescent nationalism.

Federal nationalism is not a dominant ideological-political formation. It is generally confined to few regions. It is represented by the fragmented communist, socialist, and regional parties. We can term their nationalism as federal nationalism; this is an ideology of seeing the Indian Nation a confederation of various ethnicities, languages and cultures and sub-cultures. It describes decentralization as a necessary condition for national unity.

They promote cultural federalism and oppose anyemphasize on dominant culture. They promote cultural diversities. However, within a region it is caste-centric; either Backward Castes or Other Backward Castes (generally not Brahminism). Familism is another nature cultural federalism.

Economy is neo-liberal but they bombard population with feebees and welfare policies. It helps them to deactivate civil society from active participation. Thereby, the neo-liberal economy and

${ }^{14}$ Christopher Jaffrelot, The Hindu Nationalist Movement in India 1925 to the 1990's (New Delhi: Penguin India, 1996), 3-7. 
its consequences are well protected. Political rhetoric is rarely on economic policies but based on fee-bees and cover-up programmes.

\section{Subaltern Nationalisms, Counter Cultures, Subal- tern Economies}

When I use this term subaltern nationalism, I understand there is no competing vision that holds us together as a nation from the subaltern communities. This paralysis of the mind is linked to their systemic cultural, intellectual and spiritual destruction. However, many fragments from many buried past times can be linked together with the existing (past) subaltern ideologies of Phule, Ambedkar and Periyar, that can pave the way to a broad-based unity of Indian society based on egalitarian principles.

At certain extent the perspective of Dalit Bahujan goes hand in hand with subaltern nationalism. However, as a social movement they cherished subaltern nationalism, when they shifted from social movement to political movement, they swing in between various factions as per the need of grabbing power.

As Mani states, "political parties dominated by the Dalitadivasies and OBCs-the DravidaMunnetraKazhagam, Samajwadi Party, Bahujan Samjwadi Party, Rashtriya Janata Dal, Jharkhand Mukti Morcha and so forth-none have a coherent cultural-national formulation..." they follow either one of the four political-ideological formulations always as per the need of the hour.

Subaltern movements both social as well as political have always expressed themselves as counter-cultural either through re-reading history, politics, religion etc., or erecting symbolic expressions to counter dominant and exploitative cultural practices.

For example, Mussahar community is one of the Dalit communities in North India, they are comparatively more in number in Bihar. They are classified as untouchable group. Being landless and in many cases homeless too, they used to wander from place to place in search of livelihood. But now they have started to build fixed settlements. Mussahar community is now part of Hindu Religion. However, they follow certain deities, who are mythical figures which belong to Mussahar community. Caste Hindus very rarely follow or worship these deities. It is interesting to note that some of these deities protested against the Hindu god-designed caste system. The major reason to keep these deities among them is to remember the act of protest. One of the striking examples of two human heroes who became deities is Dina-Bandri.

The single name Dina-Bhandri is actually the names of two men, combined, namely Dina and Bhadri. They were two brothers born to a person named Kalu, who was a Mussahar in Nepal. Kalu and his wife had the two boys in their old age after they received a promise from a deity that they would be blessed with two children. Both children were very healthy, as they grew up, they learned wrestling.
Being of Dalit community, Kalu was ill-treated by Jamindar, named JerovarRai. He had 700 wrestlers (pehalwans) under his care, who he used to terrorize the Mussahar community members and force them to work for him. To display his strength JerovarRai would very often organize wrestling events between his wrestlers in public arena. During this occasion they would challenge other pehalwans. One day Dina and Bhandri openly challenged JerovarRai. Annoyed, JerovarRai had no other option but to accept their challenge and to fight with them. Dina and Bhandri won the wrestling and killed JerovarRai in the fight. In this way, two brother could get freedom for their community. After these, Mussahar community considered Dina and Bhandri as warrior deity. They together are called DinaBhandri.

Dina-Bhandri's statute or idol is placed in the middle of the village. Every year villagers offer worship with a lot of jubilation. The village deity, they believe, is the protector of their race.

Dina-Bhandri worship is chosen for a particular month of the year as per the convenience and consent of the community who will offer the worship. In the chosen month villagers decide a particular day, again by consent. On the day of the worship villagers take bath early in the morning and go to the site where Dina Bhandri is installed. They clean the area. Sweets and pudding are special delicacies in the form of prasad which are eaten on the day.

The villagers irrespective of whether they are young or old surround Dina-Bhandri. Music of Madal and Dholak accompanies the verses chanted by the villagers amidst much fun and revelry. Three bamboo poles with red and white flags, put up as the symbol of three deities namely Dina, Bhandri and Salahesh (disciple of Dina and Bandri), stand in the centre. They are replaced with new ones only in the following year on the day of Dina Bhandri. Once the poles are replaced villagers offer worship with flowers, incense and so on they have brought with them for puja. Then verses rend the air as the villagers led by Dhami (priest) in front begin a journey to the jungles. In fact they go to a certain place specified for the purpose and return, all the while chanting the verses before the worship is declared finished. The verses, which obviously are long, rend the air throughout the day ${ }^{15}$.

This mythical tradition talks about the history of protest, protesting against caste system. Mussahar community replaced caste-ordained gods with either caste-destroying gods or anticaste god. The faith expressed in Musahar (Dalit) religion is the expression of their protest against the dominant myth which established the status quo of the caste system.

Despite this, the majority of Musahars are brainwashed to believe Dinabandhri is a local avatar of Vishnu Bhagavan. God of the Brahmin is identified in Musahar as Dinabandri, thus they belong to the fold of Hinduism.

${ }^{15}$ James Masse y, Dalit Heritage and Liberative Traditions(New Delhi: CDS, 015) 07. 
In contrast to neo-liberal economy, subaltern economies concentrate on livelihood issues locally. Economy of fishing and Tribal communities, Adivasies etc. are generally considered as subaltern economies. Those economies are being suppressed or destroyed by the dominant (neo-liberal) economy. Today social movements are generally standing for the cause of subaltern economies.

\section{Concluding Remarks}

The above analysis gives a bird's-eye view of the political and ideological framework of Indian society. The swing of the nation between these frameworks is well defined by the religiously-rooted psyche of the mass. Community-centred conscience/psyche always has a positive side; however, in the Indian context largely it works towards the opposite end. Knowing the condition, the political parties take advantage of the mass psyche andfail to rebuild or reorient the community. For establishing power, many political parties either use communal violence as its prerequisite or keep themselves away during the violence andbecome active after the violence. Nothing changes but time after time they cut and re-stitch the fabric of the nation.
To Submit Your Article Click Here: Submit Article

DOI: $10.32474 / J A A S .2020 .02 .000129$

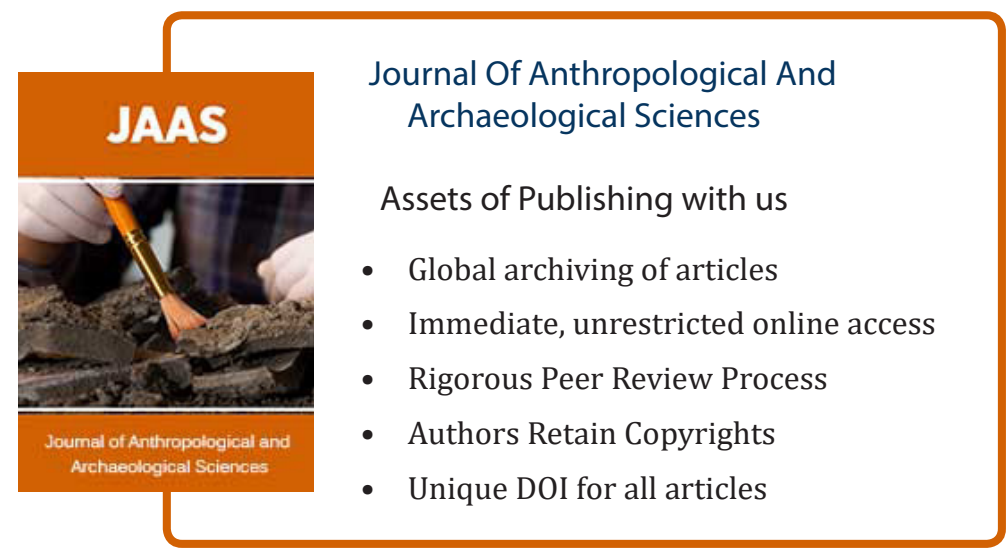

